\title{
Prevalence and associated factors of thrombocytopenia among HAART naive HIV positive patients at Gondar university hospital, northwest Ethiopia
}

Yitayih Wondimeneh, Dagnachew Muluye and Getachew Ferede*

\begin{abstract}
Background: Hematological abnormalities are common in HIV positive patients. Of these, thrombocytopenia is a known complication which has been associated with progression of disease. However, its magnitude and associated factors in HAART naive HIV positive patients is not known in Ethiopia. Therefore, the aim of this study was to determine the prevalence and associated factors of thrombocytopenia in HAART naïve HIV positive patients.

Methods: A retrospective study was carried out among HAART naive HIV positive patients at Gondar University Hospital, Northwest Ethiopia, from September 2011 through August 2012. Socio-demographic variables and immunohematological (platelets and CD4+ T cells) values were carefully reviewed from medical records. Associated factors and outcomes were assessed using logistic regression.

Results: A total of 390 HAART naive HIV positive patients with a mean age of 33.65 years and a range of 18-70 years were reviewed. The overall prevalence of thrombocytopenia was 23(5.9\%). The mean CD4 count was $288 \pm 188.2$ cells/ $\mu \mathrm{L}$. HIV patients whose age $\geq 50$ years old were 2.5 times more likely to have thrombocytopenia and those patients whose CD4 count $<350$ were 2.6 times more likely to have thrombocytopenia than HIV patients whose CD4 count $\geq 500$. However, $C_{4}$ count was not statistically associated with prevalence of thrombocytopenia $(P>0.05)$.
\end{abstract}

Conclusion: As CD4 counts of HIV patients decreasing, they have more likely to have thrombocytopenia. Therefore, early diagnosis and treatment of thrombocytopenia in these patients are necessary.

Keywords: Thrombocytopenia, HIV, HAART naive, CD4 count

\section{Background}

Human immunodeficiency virus (HIV) is a retrovirus that infects cells of the immune system, destroying or impairing their function, which leads to the occurrence of opportunistic infections and tumors [1]. Though the malfunction of the immune system and the decrease in the number and activity of CD4+ T cells signify the hallmark of HIV infection, it is notable that HIV can also impede with other cell lineages and tissues [2,3]. In addition to progressive reduction of CD4+ T cells, peripheral blood cytopenias, such as

\footnotetext{
* Correspondence: get29f@gmail.com

School of Biomedical and Laboratory Sciences, College of Medicine and Health Sciences, University of Gondar, P.O. Box 196, Gondar, Ethiopia
}

anaemia, neutropenia and thrombocytopenia, happen in most patients with AIDS [4,5].

Peripheral blood cytopenias have been showed even in the absence of chemotherapeutic treatment or opportunistic infections and tumours, signifying that HIV infection may be directly associated with the induction of these hematological abnormalities [6]. Intriguingly, identified thrombocytopenia can signify the first clinical manifestation in otherwise asymptomatic HIV positive patients [7] while neutropenia and anaemia are more common in the late stages of HIV disease [8].

Thrombocytopenia is characterized by platelet counts below $125 \times 10^{3} / \mathrm{mm}^{3}$, and also frequently occurs in HIVinfected patients [9-11]. Its pathogenesis has not yet been
Ciomed Central

(c) 2014 Wondimeneh et al.; licensee BioMed Central Ltd. This is an open access article distributed under the terms of the Creative Commons Attribution License (http://creativecommons.org/licenses/by/2.0), which permits unrestricted use, distribution, and reproduction in any medium, provided the original work is properly cited. 
recognized. Possible mechanisms that have been reported are increased platelet destruction, either caused by the nonspecific deposition of circulating immune complexes on platelets or by the presence of specific anti-platelet antibodies, as well as direct infection of megakaryocytes by HIV with a resulting ineffective in platelet production[12].

Incidence of thrombocytopenia is around 40\% of HIVinfected persons, and in approximately $10 \%$ of the patients, it may be the first sign of AIDS [13]. This haematological disorder may represent the first manifestation of HIV infection and it may progress over time and lead to severe bleeding [14]. Mature Megakaryoctes (MKs) can be infected by HIV through binding the CD4 receptor [15], and HIV genomes have been detected in MKs purified from bone marrow (BM) of HIV-positive patients [16].

The infection of MKs is not strain-restricted because both R5- and X4-tropic HIV-1 strains are able to infect MKs thus indicating that the infection may occur early in the development of HIV infection [17]. In addition to these direct effects of HIV on the MK cell lineage, HIV also supports chronic thrombocytopenia through autoimmune mechanisms [14], particularly manifest in early stages of the disease [18]. Autoimmune mechanisms are associated to anti-HIV antibodies cross-reacting with platelet-membrane glycoproteins, supporting the basic role of molecular mimicry in the induction of these antibodies [19].

Thrombocytopenia is associated with increased morbidity and mortality, accelerated deterioration in CD4 counts and accelerated progression to AIDS [20]. The incidence of thrombocytopenia varied according to the definition of thrombocytopenia and the characteristics of the baseline population [21]. There is no such information for HIVinfected individuals in Ethiopia which may help to inform respective bodies for treatment of HIV-infected individuals in this area. We therefore assessed the prevalence of thrombocytopenia in HIV-infected HAART naive patients and also tried to determine the relationship between thrombocytopenia and CD4 cell counts in these patients.

\section{Methods}

A retrospective study was carried out among HAART naive HIV positive patients at Gondar University Hospital, Northwest Ethiopia, from September 2011 through August 2012. Gondar University Hospital provides HIV/AIDS interventions including free diagnosis, treatment and monitoring. The center diagnoses new cases and monitors those on therapy. Patients on interferon therapy, chemotherapy, or malignancy were excluded.

Socio-demographic variables and immunohematological (platelets and CD4+ T cells) values were carefully reviewed retrospectively from medical records. Reviewed laboratory data of platelets analyses were done using the automated blood analyzer Cell-Dyn 1800 (Abott Laboratories Diagnostics Division, USA) and CD4 T lymphocyte counts were done using the Becton Dickinson FACS count. Thrombocytopenia was defined as platelets count $<125.0 \times 10^{3} / \mathrm{mm}[22,23]$.

SPSS version 16 statistical software was used for analysis of the data. Descriptive statistics (minimum, maximum, mean and standard deviation) were used for continuous variables in the course of analysis and categorical data were analyzed using logistic regression. A P-value of $<0.05$ was considered to be statistically significant.

Ethical clearance was obtained from the Institutional Ethical Review Board of University of Gondar and Permission for data collection was also obtained from the University Hospital.

\section{Result}

A total of 390 HAART naïve HIV positive patient results were reviewed from their medical records. Out of these, 271 (69.5\%) were females. The mean age of the patients was $33.65 \pm 9.1$ years, ranging from $18-70$ years. The majority of study participants 328 (84.1\%) were urban residents (Table 1).

The overall prevalence of thrombocytopenia was 23 (5.9\%). Platelet levels of the study participants were between $29 \times 10^{3}$ cells $/ \mu$ l and $653 \times 10^{3}$ cells $/ \mu$ l with the mean of $258 \times 10^{3} \pm 100.561$ cells $/ \mu$ l. The minimum CD4 count was 9 cells $/ \mu \mathrm{L}$, and the maximum was 1280 cells $/ \mu \mathrm{L}$. The mean CD4 count was $288 \pm 188.2$ cells $/ \mu L$. In this study, majority of the thrombocytopenia cases 12 (7.3\%) were observed in the age group of 30-39 years. However, the difference was not statistically significant. HIV patients whose age $\geq 50$ years old were 2.5 times more likely to have

Table 1 Socio-demographic characteristics of HAART naive HIV positive patients at Gondar university hospital, northwest Ethiopia, 2013

\begin{tabular}{lll}
\hline Variables & Frequency & Percentage (\%) \\
\hline Sex & 119 & 30.5 \\
Male & 271 & 69.5 \\
Female & & \\
Age in years & 125 & 32.1 \\
$18-29$ & 165 & 42.3 \\
$30-39$ & 74 & 19 \\
$40-49$ & 26 & 6.7 \\
$50 \&$ above & & \\
Residence & 328 & 84.1 \\
Urban & 62 & 15.9 \\
Rural & & \\
Religion & 358 & 91.8 \\
Christian & 30 & 7.7 \\
Muslim & 2 & 0.5 \\
Others &
\end{tabular}


Table 2 Prevalence of thrombocytopenia among HAART naive HIV positive patients at Gondar university hospital, northwest Ethiopia, 2013

\begin{tabular}{lll}
\hline Platelet count & Frequency & Percentage (\%) \\
\hline$\geq 125.0 \times 10^{3} / \mathrm{mm}$ & 367 & 94.1 \\
$<125.0 \times 10^{3} / \mathrm{mm}$ & 23 & 5.9 \\
Total & 390 & 100 \\
\hline
\end{tabular}

thrombocytopenia and those patients whose CD4 counts < 350 were 2.6 times more likely to have thrombocytopenia than HIV patients whose CD4 count $\geq 500$ (Tables 2 and 3).

\section{Discussion}

Increasing the intricacy of HIV infection, varied hematological manifestations can be seen, in which HIV related thrombocytopenia is one of them [24]. We assessed platelet counts in HAART naive HIV infected patients, which showed that $5.9 \%$ of the sample population had thrombocytopenia, which was in agreement with previous studies by Denue et al.,[25], Sloand et al.,[21], Sullivan et al.,[26], and Suresh et al., [27]. However, lower than reported by Erhabor et al., [28] and Akinsegun et al.,[29]. This problem is truly a medical challenge in vulnerable population, especially by the limited therapeutic options and the absence of intervention protocol for HIV subjects [9].

Results from this study showed that majority of HAART-naïve HIV positive patients were females. The female prevalence in this study confirms the World Health Organization (WHO) report that HIV/AIDS affects females most severely in sub-Saharan Africa [30,31]. However, thrombocytopenia had not showed statistical significance with sex and age $(\mathrm{p}>0.05)$. This was in agreement with previous study done by Majluf-Cruz [24].

According to the present study, as immunity of a patient decreasing, thrombocytopenia was more prevalent rather than HIV positive patients who have relatively high CD4 count. For example, the prevalence of thrombocytopenia was proportionally high among patients who had a CD4 lymphocyte count of $\leq 350$ cells $/ \mu \mathrm{L}$ and low among patients with a CD4 count $>500$ cells $/ \mu \mathrm{L}$. However, the increase in prevalence of thrombocytopenia with decreased CD4 cell count was not statistically significant $(P>0.05)$. Similar findings have been reported by Elisaphane et al., [32], Ira and Bhushan [33].

To the best of our knowledge, this is the first study in Ethiopia to determine prevalence of thrombocytopenia in HAART-naïve HIV infected patients. However, this study had limitations such as its retrospective nature which introduces possible biases related to ascertainment, documentation and chart review. In addition, this study was not included HIV infected patients who had on HAART. However, the observed results may still be a good reflection of a true circumstances and this study serve as a reference for additional recommendations to improve care of HIV infected persons and a step for further studies on the pathophysiology of HIV associated thrombocytopenia.

\section{Conclusion}

In conclusion, as CD4 counts of HIV patients decreasing, they have more likely to have thrombocytopenia. Based on this finding, it is recommended that physicians giving care for HIV infected individuals should routinely investigate and treat thrombocytopenia.

Table 3 Association of thrombocytopenia with related factors among HAART naïve HIV positive patients at Gondar university hospital, northwest Ethiopia, 2013

\begin{tabular}{|c|c|c|c|c|c|}
\hline \multirow[t]{2}{*}{ Variables } & \multicolumn{2}{|c|}{ Thrombocytopenia } & \multicolumn{2}{|c|}{ OR $(95 \% \mathrm{Cl})$} & \multirow[t]{2}{*}{ P-value } \\
\hline & Yes (\%) & No (\%) & Crude & Adjusted & \\
\hline Sex & & & & & 0.49 \\
\hline Male & $9(7.6)$ & $110(92.4)$ & 1 & 1 & \\
\hline Female & $14(5.2)$ & 257(94.8) & $0.7(0.28-1.58)$ & $0.7(0.30-1.79)$ & \\
\hline Age & & & & & 0.46 \\
\hline $18-29$ & $5(4)$ & $120(96)$ & 1 & 1 & \\
\hline $30-39$ & $12(7.3)$ & 153(92.7) & $1.9(0.65-5-49)$ & $1.7(0.57-5.06)$ & \\
\hline $40-49$ & $3(4.1)$ & $71(95.9)$ & $1.0(0.24-4.37)$ & $0.8(0.19-3.81)$ & \\
\hline$\geq 50$ & $3(11.5)$ & $23(88.5)$ & $3.1(0.70-14.02)$ & $2.5(0.54-11.66)$ & \\
\hline CD4 count & & & & & 0.57 \\
\hline$<350$ & $19(6.8)$ & 260(93.2) & $3.14(0.41-24.08)$ & $2.6(0.33-20.61)$ & \\
\hline $350-499$ & $3(4.5)$ & $64(95.5)$ & $2.02(0.20-20.02)$ & $1.8(0.17-17.89)$ & \\
\hline$\geq 500$ & $1(2.3)$ & 43(97.7) & 1 & 1 & \\
\hline
\end{tabular}

Note: 1- reference group. 


\section{Competing interests}

The authors declared no conflicts of interest with respect to the authorship and/or publication of this article.

\section{Authors' contributions}

YW: Participated in the conception and design of the study, data collection, analysis and interpretations of the findings, reviewed the manuscript. DM: Participated in the conception and design of the study, analysis and interpretations of the findings, reviewed the manuscript. GF: Participated in the conception and design of the study, data collection, analysis and interpretations of the findings, drafting the manuscript and write up. All authors read and approved the final manuscript.

\section{Acknowledgements}

The authors wish to acknowledge Gondar University Hospital staffs for facilitating the data collection.

Received: 15 July 2013 Accepted: 2 January 2014

Published: 6 January 2014

\section{References}

1. Levy JA: HIV pathogenesis, 25 years of progress and persistent challenges. AIDS 2009, 23:147-160.

2. Borderi M, Gibellini D, Vescini F, Crignis De Cimatti E, Biagetti L, Tampellini C: Metabolic bone disease in HIV infection. AIDS 2009, 23:1297-1310.

3. Gandhi RT, Sax PE, Grinspoon SK: Metabolic and cardiovascular complications in HIV-infected patients: new challenges for a new age. $J$ Infect Dis 2012, 3:353-4.

4. Zon LI, Arkin C, Groopman JE: Haematologic manifestations of the human immune deficiency virus (HIV). J Haematol 1987, 66:251-256.

5. Moses A, Nelson J, Bagby GC: The influence of human immunodeficiency virus-1 on hematopoiesis. Blood 1998, 91:1479-1495.

6. Alexaki A, Wigdahl B: HIV-1 infection of bone marrow hematopoietic progenitor cells and their role in trafficking and viral dissemination. PLoS Pathog 2008, 4:e1000215.

7. Ratner L: Human immunodeficiency virus-associated autoimmune thrombocytopenic purpura. Am J Med 1989, 86:194-198.

8. Davis BR, Zauli G: Effect of human immunodeficiency virus infection on haematopoiesis. Baillieres Clin Haematol 1995, 8:113-130.

9. Miguez-Burbano MJ, Jackson J, Hadrigan S: Thrombocytopenia in HIV disease: clinical relevance, physiopathology and management. Curr Med Chem Cardiovasc Hematol Agents 2005, 3:365-76.

10. Kirchhoff F, Silvestri G: Is Nef the elusive cause of HIV-associated hematopoietic dysfunction? J Clin Invest 2008, 118:1622-5.

11. Dilkshit B, Wanchu A, Sachdeva RK, et al: Profile of hematological abnormalities of Indian HIV infected individuals. BMC Blood Disorders 2009, 9:5.

12. Jost J, Tauber MG, Luthy R, et al: HIV-associated thrombocytopenia. Schweiz Med Wochenschr 1988, 118:206-212.

13. Pechere M, Samii K, Hirschel B: HIV related thrombocytopenia. Engl J Med 1993, 328:1785-6.

14. Scaradavou A: HIV-related thrombocytopenia. Blood Rev 2002, 16:73-76.

15. Zucker-Franklin D, Cao YZ: Megakaryocytes of human immunodeficiency virus-infected individuals express viral RNA. Proc Natl Acad Sci USA 1989, 86:5595-5599.

16. Zucker-Frankli D, Termin CS, Cooper MC: Structural changes in the megakaryocytes of patients infected with the human immune deficiency virus (HIV-1). Am J Pathol 1989, 134:1295-1303.

17. Voulgaropoulou F, Pontow SE, Ratner L: Productive infection of CD34 + -cell-derived megakaryocytes by X4 and R5 HIV-1 isolates. Virology 2000, 269:78-85.

18. Murphy MF, Metcalfe P, Waters AH, Carne CA, Weller IV, Linch DC, Smith A Incidence and mechanism of neutropenia and thrombocytopenia in patients with human immunodeficiency virus infection. $\mathrm{Br} J$ Haematol 1987, 66:337-340.

19. Karpatkin S, Nardi M, Lennette ET, Byrne B, Poiesz B: Anti-human immunodeficiency virus type 1 antibody complexes on platelets of seropositive thrombocytopenic homosexuals and narcotic addicts. Proc Natl Acad Sci USA 1988, 85:9763-9767.

20. Volberding PA, Baker KR, Levine AM: Human immunodeficiency virus hematology. American Society of Haemotology Annual Meeting; 2003:294-312.
21. Sloand EM, Klein HG, Banks SM, Vareldzis B, Merritt S, Pierce P: Epidemiology of thrombocytopenia in HIV infection. Eur J Haematol 1992, 48:168-72.

22. Steinman RM, Granelli-Piperno A, Pope $M$, et al: The interaction of immunodeficiency viruses with dendritic cells. Curr Top Microbiol Immunol 2003, 276:1-30

23. World Health Organisation: Nutritional anemia: report of a WHO scientific group. Geneva, Switzerland: World Health Organisation; 1968.

24. Majluf-Cruz A: Changes in blood coagulation in HIV infection. Rev Invest Clin 1997, 49:51-66.

25. Denue BA, Gashau W, Bello HS, Kida M, Bakki B, Ajayi B: Relation between some haematological abnormalities, degree of immunosuppression and viral load in treatment-naïve HIV-infected patients. EMHJ 2013, 19:4.

26. Sullivan PS, Hanson DL, Chu SY, Jones JL, Ciesielski CA: Surveillance for thrombocytopenia in persons infected with HIV: results from the multistate adult and adolescent spectrum of disease project. JAIDS 1997, 14:374-379.

27. Suresh Venkata Satya A, Singh VP, Madhukar R, Datla Vivekananda V, Gulati AK, Shyam S: Hematological profile of HIV patients in relation to immune status - a hospital-based cohort from Varanasi, North India. Turk J Hematol 2008, 25:13-19.

28. Erhabor O: Some haematological parameters in human immunodeficiency virus (HIV) infected Africans: the Nigerian perspective. Niger J Med 2005, 14:33-38.

29. Akinsegun A, Olajumoke O, Titilope A, et al: Hematologic abnormalities in treatment naïve HIV patients. Infectious Diseases Research and Treatment 2010, 3:45-49.

30. Dabis F, Ekpini ER: HIV-1/AIDS and maternal and child health in Africa. Lancet 2002, 359:2097-104.

31. Joint United Nations Programme on HIV/AIDS and World Health Organization: AIDS epidemic update: Dec 2004. Geneva, Switzerland: UNAIDS; 2004

32. Elisaphane $M$, Ivan $E$, Eugene $M$, et al: Assessment of haematological parameters in HIV-infected and uninfected Rwandan women: a cross-sectional study. BMJ Open 2012, 2:e001600.

33. Ira S, Bhushan K: Hematological manifestation in haart naive hiv-1 infected children in india in a resource limited setting. PIDC 2011, 8:35.

doi:10.1186/1756-0500-7-5

Cite this article as: Wondimeneh et al:: Prevalence and associated factors of thrombocytopenia among HAART naive HIV positive patients at Gondar university hospital, northwest Ethiopia. BMC Research Notes 2014 7:5.

\section{Submit your next manuscript to BioMed Central and take full advantage of:}

- Convenient online submission

- Thorough peer review

- No space constraints or color figure charges

- Immediate publication on acceptance

- Inclusion in PubMed, CAS, Scopus and Google Scholar

- Research which is freely available for redistribution 